\title{
Work-to-family interface and well-being: The role of workload, emotional load, support and recognition from supervisors
}

\begin{tabular}{|c|c|}
\hline \multicolumn{2}{|c|}{$\begin{array}{l}\text { Authors: } \\
\text { Audrey Babic } \\
\text { Nicolas Gillis } \\
\text { Isabelle Hansez }\end{array}$} \\
\hline \multicolumn{2}{|c|}{$\begin{array}{l}\text { Affiliations: } \\
{ }^{1} \text { Human Resources } \\
\text { Development Unit, Work } \\
\text { Psychology Department, } \\
\text { Faculty of Psychology, Speech } \\
\text { and Language Therapy, and } \\
\text { Education, University of } \\
\text { Liège, Liège, Belgium }\end{array}$} \\
\hline \multicolumn{2}{|c|}{$\begin{array}{l}{ }^{2} \text { Mental Readiness and } \\
\text { Psychosocial Advisor, Belgian } \\
\text { Defence, Marche-en- } \\
\text { Famenne, Belgium }\end{array}$} \\
\hline \multicolumn{2}{|c|}{$\begin{array}{l}\text { Corresponding author: } \\
\text { Audrey Babic, } \\
\text { audrey.babic@uliege.be }\end{array}$} \\
\hline \multicolumn{2}{|c|}{$\begin{array}{l}\text { Dates: } \\
\text { Received: } 16 \text { Jan. } 2019 \\
\text { Accepted: } 16 \text { Oct. } 2019 \\
\text { Published: } 17 \text { Mar. } 2020\end{array}$} \\
\hline \multicolumn{2}{|c|}{$\begin{array}{l}\text { How to cite this article: } \\
\text { Babic, A., Gillis, N., \& Hansez, } \\
\text { I. (2020). Work-to-family } \\
\text { interface and well-being: The } \\
\text { role of workload, emotional } \\
\text { load, support and recognition } \\
\text { from supervisors. SA Journal } \\
\text { of Industrial Psychology/SA } \\
\text { Tydskrif vir Bedryfsielkunde, } \\
46(0) \text {, a1628. https://doi. } \\
\text { org/10.4102/sajip.v46i0.1628 }\end{array}$} \\
\hline \multicolumn{2}{|c|}{$\begin{array}{l}\text { Copyright: } \\
\text { (C) 2020. The Authors } \\
\text { Licensee: AOSIS. This } \\
\text { is licensed under the } \\
\text { Creative Commons } \\
\text { Attribution License. }\end{array}$} \\
\hline \multicolumn{2}{|l|}{ Read online: } \\
\hline 回的回 & $\begin{array}{l}\text { Scan this QR } \\
\text { code with your } \\
\text { smart phone or } \\
\text { mobile device } \\
\text { to read online. }\end{array}$ \\
\hline
\end{tabular}

Orientation: Considering the negative and positive consequences of burnout and work engagement, respectively (i.e. concepts used in reference to well-being), for both workers and organisations, it is crucial to identify their antecedents in order to prevent burnout and foster work engagement.

Research purpose: We investigated the mediating role of work-to-family conflict (WFC) and work-to-family enrichment (WFE) in the relationships between work environment (i.e. emotional load and workload as job demands; support and recognition from supervisors as job resources) and well-being (i.e. work engagement and burnout). The buffering effect of job resources in the job demands-WFC relationships was also tested.

Motivation for the study: The present research tries to respond to recent recommendations in the field of work-family interface and burnout.

Research approach/design and method: A total of 226 employees of a Belgian Federal Public Service were surveyed. Our cross-sectional research model was tested using structural equation modelling with Mplus.

Main findings: Workload and support were related to WFC, whereas only recognition was related to WFE. Both WFC and WFE were related to work engagement and burnout. The two job resources buffered the workload-WFC relationship.

Practical/managerial implications: Supervisors can increase WFE by recognising employees' efforts and reduce WFC by promoting a supportive work environment and reducing the workload. By doing so, supervisors increase work engagement and decrease burnout, thus enhancing workers' well-being.

Contribution/value-addition: This study highlights that the two job resources operate in different ways regarding work-to-family interface: recognition activates the resource generation and motivational processes, whereas support operates in the resource depletion and health impairment processes. The role of supervisors is thus crucial in the emergence of workers' well-being.

Keywords: JD-R model; work-to-family interface; recognition from supervisor; support from supervisor; burnout; work engagement.

\section{Introduction}

Nowadays, employees are more likely than ever to be concerned with how to manage their work and family lives. Several factors explain that satisfying the demands of work and family is one of the biggest challenges for employees (Kinnunen, Rantanen, Mauno, \& Peeters, 2014). These factors mainly include changes in the composition of the workforce, demographic shifts, or changes or advances in technology. Moreover, globalisation and competition between companies have placed a burden on workers and organisations, pushing them to be more flexible and responsive to changes in working life. Indeed, pressures at work have increased in recent decades (Kuschel, 2017), therefore increasing the probability for workers to have difficulties in managing work and family. All of these factors have considerably blurred the lines between work and family, modifying the way in which individuals manage their work and family domains (e.g. Kinnunen et al., 2014). Therefore, managing the work-family interface is becoming not only increasingly important but also increasingly complex.

Over the years, a substantial number of papers have identified that the work-family interface (i.e. work-family conflict and enrichment) has a significant influence on a variety of well-being 
variables, such as burnout and work engagement (e.g. Babic, Stinglhamber, Bertrand, \& Hansez, 2017; Baeriswyl, Krause, \& Schwaninger, 2016; Verweij et al., 2017; Wayne, Musisca, \& Fleeson, 2004). Considering the negative and positive consequences of burnout and work engagement, respectively, for both workers and organisations, it is crucial to identify their antecedents in order to prevent employee burnout and foster employee work engagement.

In line with this objective, the job demands and resources model (JD-R model, Bakker \& Demerouti, 2008, 2017), a welltested and widely used theoretical framework for describing the relationships between work characteristics and wellbeing, is often mobilised to explain the emergence of burnout and work engagement. For example, studies investigating the role of work-to-family conflict (WFC) as a lever in the health impairment process of the JD-R model found that work characteristics (e.g. workload, supervisors support) were related to WFC which in turn was related to emotional exhaustion (e.g. Baeriswyl et al., 2016).

Even if there is a plethora nowadays of studies applying the JD-R model, some recommendations have been made to better understand the influence of work-related factors on work-family interface and well-being outcomes. Baeriswyl et al. (2016) suggested to not only focus on the negative side of the interface (WFC) but also to explore the role of the positive side (i.e. work-to-family enrichment; WFE) in the motivational processes of the JD-R model.

Indeed, several authors have recommended integrating both conflict and enrichment into research on work-family interface (e.g. Carlson, Kacmar, Wayne, \& Grzywacz, 2006). Conflict and enrichment are not opposite of each other but co-exist (Grzywacz \& Butler, 2005). One may experience more conflict or enrichment at certain times in life, but both are always present (e.g. Rantanen, Kinnunen, Mauno, \& Tement, 2013).

Therefore, focusing on only one of the two sides of the workfamily interface may limit the understanding of the processes influencing work-family issues (Boz, Martínez-Corts, \& Munduate, 2016).

Baeriswyl et al. (2016) also suggested testing the interactive effects of job demands and job resources (i.e. JD-R model; Bakker \& Demerouti, 2008, 2017) by investigating the moderating effects of job resources such as supervisor's support in the health impairment process of the JD-R model.

\section{Research purpose and objectives}

In this study, we tried to respond to recommendations formulated by Baeriswyl et al. (2016) by investigating the mediating role of WFC and WFE in the relationship between some work characteristic variables (i.e. emotional load and workload as job demands; supervisors support and recognition from supervisors as job resources) and well-being outcomes (i.e. work engagement and burnout). Moreover, we tested the buffering effect of job resources on the job demands-WFC relationships.

This research focused on workload (having a lot of work to do within a short time span; Baeriswyl et al., 2016), emotional load (the affective component of work and the degree to which one's work puts one in emotionally stressful situations; Peeters, Montgomery, Bakker, \& Schaufeli, 2005) and supervisor support (workers' perceptions concerning the degree to which their supervisors care about their well-being and value their contributions; Eisenberger, Huntington, Hutchison, \& Sowa, 1986) because they have been consistently recognised as crucial for the majority of employees across different occupations (e.g. Bakker \& Demerouti, 2007). We included recognition from supervisors (spontaneous, sincere and personal appreciation of employee efforts; Yoo, Shin, \& Yang, 2006) because it is an important variable that predicts high levels of burnout and low psychological well-being (Amutio, Ayestaran, \& Smith, 2009). While we recognise that work-family conflict and enrichment are bidirectional (i.e. perceptions of conflict and enrichment not only from work to family but also from family to work; Greenhaus \& Beutell, 1985; Greenhaus \& Powell, 2006), the present research focused only on the work-to-family direction (i.e. WFC and WFE) considering that work-related variables (i.e. JD-R) are more likely to predict these types of work-family interfaces (e.g. Michel, Kotrba, Mitchelson, Clark, \& Baltes, 2011).

\section{Literature review Burnout and work engagement}

Instead of being two opposite poles, burnout and engagement are viewed as independent, yet negatively correlated states of mind (Schaufeli \& Bakker, 2004). Burnout was defined as 'a syndrome of chronic exhaustion, a cynical, negative attitude regarding work, and reduced professional efficacy that could occur in any job (Maslach, Schaufeli, \& Leiter, 2001)' (Bakker \& Demerouti, 2017, p. 273). Burnout is a tripartite syndrome (Maslach et al., 2001) consisting of emotional exhaustion, feelings of depersonalisation (also disengagement) and a diminished sense of personal accomplishment. Emotional exhaustion refers to 'the depletion or draining of emotional resources caused by interpersonal demands' (Schaufeli \& Salanova, 2014 , p. 296). Depersonalisation refers to 'the development of negative, callous and cynical attitudes towards the recipients of one's services' (Schaufeli \& Salanova, 2014, p. 296). Reduced personal accomplishment is 'the tendency to evaluate one's work with recipients negatively' (Schaufeli \& Salanova, 2014, p. 296). Although the multidimensional nature of this construct has been vigorously debated (e.g. Maslach et al., 2001), many researchers advocate a two-dimensional concept. For example:

Schaufeli and Taris (2005) argued that exhaustion and depersonalization constitute the core of burnout and that rather than being a constituting dimension, reduced personal accomplishment should be a consequence of exhaustion and depersonalization. (Schaufeli \& Salanova, 2014, p. 297) 
Therefore, researchers argued that the specificity of the burnout syndrome lies in the combination of general reactions linked to stress (i.e. exhaustion dimension) and specific attitudinal manifestations that signal a crisis in the individual-work relationship (i.e. depersonalisation dimension) (Schaufeli \& Salanova, 2014). Therefore, throughout the present study, we focused on these two principal components of burnout (i.e. exhaustion and depersonalisation).

Since the beginning of the 21st century and with the influence of positive psychology (Seligman \& Csikszentmihalyi, 2000), research has begun to focus on a phenomenon more positive in nature, that is, work engagement. Work engagement refers to 'a positive, fulfilling, work-related state of mind that is characterized by vigor, dedication, and absorption' (Schaufeli, Salanova, Gonzalez-Roma, \& Bakker, 2002, p. 74). Vigour is 'characterized by high levels of energy and mental resilience while working, the willingness to invest effort in one's work and persistence even in the face of difficulties' (Schaufeli \& Salanova, 2014, p. 300). Dedication refers to 'being strongly involved in one's work and experiencing a sense of significance, enthusiasm, inspiration, pride and challenge' (Schaufeli \& Salanova, 2014, p. 300). Absorption is 'characterized by focused attention, being fully concentrated and happily engrossed in one's work, whereby time passes quickly and one has difficulties detaching oneself from work' (Schaufeli \& Salanova, 2014, p. 300).

The JD-R model is mainly used to explain burnout (e.g. Bakker, Demerouti, \& Euwema, 2005) and work engagement (e.g. Bakker, Hakanen, Demerouti, \& Xanthopoulou, 2007). This model assumes that all types of job characteristics can be modelled using two different categories, namely, job demands and job resources (Proposition 1; Bakker \& Demerouti, 2017). Job demands refer to 'physical, psychological, social, or organizational aspects of the job that require sustained physical and/or psychological effort and are therefore associated with certain physiological and/or psychological costs' (Bakker \& Demerouti, 2017, p. 274). Job resources describe:

$[P]$ hysical, psychological, social, or organizational aspects of the job that are functional in achieving work goals, reduce job demands and the associated physiological and psychological costs, and/or stimulate personal growth, learning, and development. (Bakker \& Demerouti, 2017, p. 274)

The central proposition of this model is the assumption of dual processes to well-being (Proposition 2; Bakker \& Demerouti, 2017). Within the first process of the JD-R model, the motivational process, job resources are assumed to activate a motivational process whereby resources may:

$[P]$ lay either an intrinsic motivational role because they foster employees' growth, learning and development, or they may play an extrinsic motivational role because they are instrumental in achieving work goals. (Schaufeli \& Bakker, 2004, p. 298)

As mentioned by Schaufeli and Salanova (2014), such resources may be located notably at the interpersonal level (i.e. social support from supervisor, recognition and rewards).
The availability of job resources stimulates employee's motivation notably in the form of work engagement (e.g. Bakker et al., 2007). This motivational process is in line with the conservation of resources (COR) theory (Hobfoll, 2002), arguing that people are motivated to obtain, retain, foster and protect things that they value most, known as resources. Therefore, individuals will try to expand these resources if possible and accumulate them. People invest resources in order to enrich their pool of resources. The idea is that initial resources generate more resources, ultimately creating a spiral gain of resources. The accumulation and gain of resources may result in positive outcomes such as better well-being (Hobfoll, 2002). According to Chen, Westman and Eden (2009), work engagement can be conceptualised as a result of continuous resource gain.

Within the second process, the health impairment process, job demands:

$[A]$ re assumed to activate an energy depletion process whereby an employee's sustained increases in effort to meet perceived job demands are met with an increase in compensatory psychological and physiological costs that drain the employee's energy. (Rich, Lepine, \& Crawford, 2010, p. 836)

This energetic process is also in line with the COR theory (Hobfoll, 2002). Over time, increasing demands threaten one's available resources. People try to react to resource losses by investing resources. However, when resource losses are not counterbalanced by resource gains in situations of resources investment, a progressing stressful process appears. This stressful process also appears when no action is taken facing situations of resource losses. When losses continue, there is an accelerated negative effect of ongoing loss spirals (i.e. loss spirals of resources) which can lead to burnout.

Consequently, job demands drain more and more individuals' resources, leading them to perceived burnout.

Even if job demands are known to play a crucial role in the health impairment process, they could also have a motivational role. In line with this idea, LePine, Podsakoff and LePine (2005) distinguished two types of job demands. The first one is the hindrance job demands that refer to 'job demands or work circumstances' (e.g. role conflict, role ambiguity, etc.) 'that involve excessive or undesirable constraints that interfere with or inhibit an individual's ability to achieve valued goals (Cavanaugh, Boswell, Roehling, \& Boudreau, 2000)' (Bakker \& Demerouti, 2017, p. 277). The second one is the challenge job demands (e.g. workload, time pressure, responsibility, etc.) that are defined as 'demands that cost effort but that potentially promote personal growth and achievement of the employees (Podsakoff, LePine, \& LePine, 2007)' (Bakker \& Demerouti, 2017 , p. 277). The latter type of demands could be considered as 'rewarding work experiences well worth the discomfort involved, and are therefore considered as "good" stressors' (Bakker \& Demerouti, 2017, p. 278). However, depending on 
the context, a challenge demand may be experienced as a hindrance demand, and vice versa.

Many empirical studies have tested these dual pathways, which have an influence on workers' well-being.

Concerning the motivational process, through their study conducted on teachers, Bakker et al. (2007) demonstrated that supervisor support enhanced work engagement. In the same vein, Laschinger and Finegan (2005) showed that recognition from supervisors was related to employees' work engagement. Even if job resources are related to such positive outcomes, they may also be related to negative outcomes. Indeed, according to the COR theory (Hobfoll, 2002), job resources should be negatively related to burnout because individuals with greater resources are more capable to meet demands and to protect themselves from the strains of further resource depletion. Empirical studies highlighted that perceived supervisor support was negatively related to burnout (e.g. Rich et al., 2010). The lack of recognition has negative consequences on variables such as burnout, turnover and a low sense of well-being (e.g. Amutio et al., 2009). Indeed, a failed reciprocity between effort and rewards is likely to elicit negative emotions, and conversely, appropriate rewards (e.g. recognition) evoke positive emotion and well-being (Siegrist, 2000).

Concerning the energetic process, meta-analyses have found that workload is amongst the key determinants of emotional exhaustion (e.g. Bowling, Alarcon, Bragg, \& Hartman, 2015). Emotional demands contributed positively to emotional exhaustion and disengagement (e.g. Verweij et al., 2017). Even if job demands are related to negative outcomes such as burnout, they may also be related to positive outcomes like work engagement. Job demands, such as workload, drain employees' energy, exhausting them mentally (Schaufeli \& Bakker, 2004). Workers perceiving that their resources are drained because of workload may engage in their work into a lesser extent in order to protect their remaining resources (Hobfoll, 2002).

\section{Work-to-family interface}

Throughout their life, people have to perform multiple social roles (i.e. parent, husband or spouse, employee, etc.). The question of compatibility of these roles is important in the prediction of workers' health and well-being. Several models or theories have been advanced to explain the relationship between work and family roles.

According to the scarcity hypothesis (Sieber, 1974), people have limited resources (i.e. time and energy) and are therefore unable to satisfy the demands of all their roles. When too many demands are placed on an individual's limited resources, he or she may experience work-family conflict generally defined as 'a form of inter-role conflict in which the role pressures from the work and family domains are mutually incompatible in some respect' (Greenhaus \& Beutell, 1985, p. 77). In situations where work-role demands impede the performance of family responsibilities, workers may perceive WFC between their work and family lives (Netemeyer, Boles, \& McMurrian, 1996).

According to the expansion theory (Sieber, 1974), by having multiple roles, individuals have access to more resources, leading them to expand their level of energy and increase their psychological well-being.

Therefore, individuals may experiment work-family enrichment when, because of participation and experience in one domain, the quality of their life in the other domain is enhanced through the transfer of resources from one role to the other (Greenhaus \& Powell, 2006). When work provides resources that enhance the individual's functioning in the family domain, workers may perceive WFE (Greenhaus \& Powell, 2006).

Job demands generally imply that employees devote such time and efforts (i.e. resources) to their work that they are left with insufficient time and energy for their personal and familial activities (i.e. depletion of resources; Bakker \& Demerouti, 2007). Amongst job demands, workload and emotional load are highlighted by numerous studies as importantly associated with WFC and/or WFE. According to the COR theory (Hobfoll, 2002), the negative effect of these job demands on employees' functioning in their family domain is because of the depletion of resources resulting from the important efforts required by workload and emotional load.

This resource depletion may hamper the amount and the effectiveness of resource transferred from the work to family domain, causing WFC and preventing WFE. Indeed, high workload reduced the perception of WFE (e.g. Grzywacz \& Marks, 2000) and increased the perception of WFC (e.g. Molino, Cortese, Bakker, \& Ghislieri, 2015), whereas emotional job demands increased the perception of WFC (e.g. Peeters et al., 2005).

Concerning job resources, a resourceful work environment creates a sense of personal control, self-esteem, self-efficacy, self-confidence, psychological resources and positive emotions (Greenhaus \& Powell, 2006), which have positive impacts on workers' ability to manage their work and family lives. Job resources may also stimulate the motivational process (Bakker \& Demerouti, 2017) facilitating enrichment between work and family. According to the enrichment process (Greenhaus \& Powell, 2006), resources gained from work may be transferred to the family in a direct way (i.e. transfer of skills, behaviours and rewards; referring to the instrumental path) or an indirect way (i.e. transfer of mood and emotions; referring to the affective path), helping individuals to perform better in the family domain. Support at work indicates that emotional and material resources or help are available when needed to allow workers to carry out their job more effectively (Rhoades \& Eisenberger, 2002). Support at work also enhances workers' perceived competence 
(i.e. self-efficacy) and a sense of being able to cope effectively with the demands of various roles (Rhoades \& Eisenberger, 2002). Social support generates feelings of love, care and value (Hobfoll, 2002) that enable individuals to more effectively transfer resources gained in one domain to the other domain. The more the employees feel supported, the more they know that help is available, perceiving WFC less and WFE more. Indeed, supervisor support has been associated with lower WFC (e.g. Bowling et al., 2015) and higher WFE (e.g. Nicklin $\&$ McNall, 2013). We are not aware of any study investigating the relationship between recognition from supervisors and WFE or WFC. However, we reasonably assume that positive emotion resulting in a reward such as recognition from a supervisor (Siegrist, 2000) and the positive psychological functioning resulting from recognition at work (i.e. autonomy, resilience, self-esteem and optimism; Merino \& Privado, 2015) can be transferred to the family domain (Greenhaus \& Powell, 2006).

Workers who feel recognised and valued by supervisors will be better able to manage their work and family lives effectively (i.e. perception of lower WFC), and enhance the quality of life in their family sphere (i.e. perception of higher WFE).

Concerning WFC's outcomes, it is well established that conflict has a negative influence on health and well-being (e.g. Amstad, Meier, Fasel, Elfering, \& Semmer, 2011). From a COR perspective (Hobfoll, 2002), resources (such as time, money, mental and physical energy, etc.) are lost in the process of managing work and family demands. When this resource depletion is not offset by resource gain, burnout occurs. Indeed, several studies found that WFC can foster emotional exhaustion (e.g. Demerouti, Bakker, \& Schaufeli, 2005) and disengagement (e.g. Verweij et al., 2017). In order to protect their remaining resources in situations of resource depletion, workers perceiving WFC are more likely to reduce their level of work engagement, which is also in line with the COR theory (Hobfoll, 2002). Indeed, WFC was found to have a negative impact on work engagement (e.g. Babic et al., 2017).

Concerning WFE's outcomes, it is established that enrichment has a positive influence on health and well-being (e.g. Zhang, Xu, Jin, \& Ford, 2018). According to the COR theory (Hobfoll, 2002), being involved in several roles has advantages for people because of greater access to resources. Work-to-family enrichment can be viewed as a resource-generating process which could protect from burnout (Tement \& Korunka, 2015). Moreover, when employees perceive that their work provides something (i.e. resources) beneficial to themselves or their family (i.e. WFE), they want to obtain or gain more resources (COR theory; Hobfoll, 2002) and consequently they get more involved in their job. Indeed, empirical research found that when people experience WFE, they report putting greater efforts into their work and being better engaged in their job (e.g. Wayne et al., 2004).
Even if research on WFE and burnout is limited (e.g. DishonBerkovits, 2014), the few studies examining these relationships found that WFE was negatively related to burnout (e.g. Verweij et al., 2017).

Therefore, based on these elements, we postulated that:

H1a: WFC will mediate the relationships between job demands (i.e. workload and emotional load) and well-being (i.e. burnout and work engagement)

H2a: WFE will mediate the relationships between job demands (i.e. workload and emotional load) and well-being (i.e. burnout and work engagement).

H1b: WFC will mediate the relationships between job resources (i.e. recognition from supervisors and perceived supervisor support) and well-being (i.e. burnout and work engagement).

H2b: WFE will mediate the relationships between job resources (i.e. recognition from supervisors and perceived supervisor support) and well-being (i.e. burnout and work engagement).

\section{Interaction effects}

In addition to the main effects of job demands and job resources on well-being (i.e. Proposition 2), the JD-R model also postulates that job resources can buffer the impact of job demands on strain (Proposition 3; Bakker \& Demerouti, 2017). In other words, job resources may offset the negative impacts of job demands on employee well-being. Several studies have provided evidence for such an interaction effect. For example, Xanthopoulou et al. (2007) conducted a study amongst home care professionals and found that job resources (i.e. autonomy, social support, performance feedback and opportunities for professional development) buffered the relationship between job demands (i.e. emotional demands, patient harassment, workload and physical demands) and burnout.

\section{Based on these elements, we postulated that:}

H3: Job resources (i.e. recognition from supervisors and perceived supervisor support) will moderate the relationships between job demands (i.e. workload and emotional load) and WFC.

Figure 1 depicts the hypothesised theoretical model.

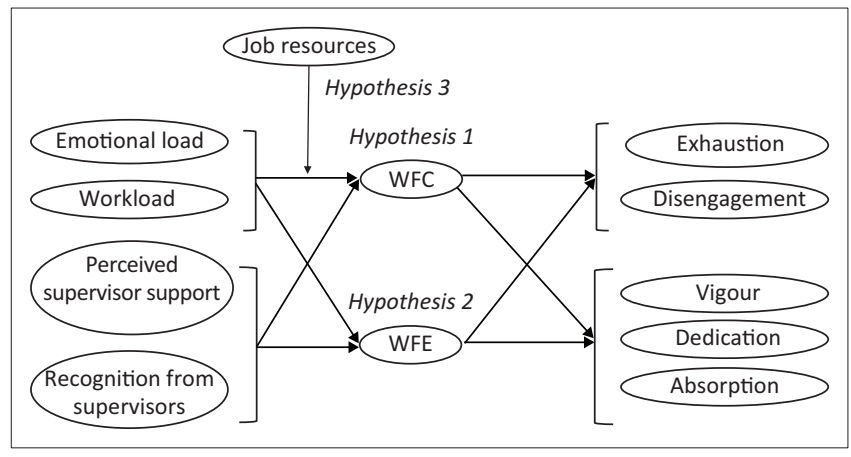

Job resources = recognition from supervisors and perceived supervisors support; WFC, workto-family conflict; WFE, work-to-family enrichment.

FIGURE 1: Hypothesised theoretical model. 


\section{Research design} Research method

\section{Research procedure and ethical considerations}

We collected data through an online survey. Participants received an email explaining the purpose of the study and emphasising the confidentiality of the responses (anonymous participation). Informed consent was obtained from each participant. This article followed all ethical standards for carrying out research.

\section{Research participants}

To test our hypotheses, an electronic questionnaire was administered to employees working in the medical division of a Belgian Federal Public Service, active in the field of security. A total of 1157 people were invited to participate in the research. People were given 1 month to complete the questionnaire, which was anonymous and confidential. We received 226 questionnaires in return, providing a response rate of about $20 \%$. This sample consisted of 120 (53\%) Dutchspeaking and 106 (47\%) French-speaking persons. Most of the respondents were men (68\%). A total of 66 participants $(29 \%)$ were employees, $82(36 \%)$ were team leaders and $38(17 \%)$ were executives. Most of the respondents (56\%) worked between $36 \mathrm{~h}$ and $40 \mathrm{~h}$ per week. One hundred and eighty-nine respondents $(84 \%)$ had been employed by their company for more than 10 years. On average, participants were 44.02 years old (standard deviation [SD] $=9.41$ ). The majority of respondents had a high school diploma (46\%) and were either married or living with a partner (51\%). Of the participants, $58 \%$ had children (22\% had one child, $23 \%$ had two and $14 \%$ had three or more children). Of the respondents, $33 \%$ had children studying in preschool or primary school, $13 \%$ had children studying in secondary school and $12 \%$ had children pursuing a university education or children in the labour market.

\section{Measuring instruments}

Questionnaires were sent in French and Dutch. We possessed some scales validated in French or in English, but not necessarily in Dutch. Therefore, we translated scales following a translation back-translation procedure (Brislin, 1980). The original English versions were first translated into French and Dutch, and then back-translated from Dutch and French to English by native speakers. In the same manner, the validated French versions were first translated into Dutch and then back-translated from Dutch to French by native speakers. For all scales, there was no major discrepancy between the original and translated versions of the scales; therefore, the translation process was considered as appropriate.

Workload was measured using the French version (Niedhammer, Chastang, Gendrey, David, \& Degioanni, 2006) of the nine items of the Job Content Questionnaire (Karasek, 1985), for example, 'My job requires working very hard'. Answers were given on a four-point Likert scale ranging from 1 (totally disagree) to 4 (totally agree).

Emotional load was measured using the seven English items of the emotional load subscale of the Questionnaire on the
Experience and Assessment of Work (Van Veldhoven \& Meijman, 1994), for example, 'Does your work demand a lot from you emotionally?'. Items were scored on a four-point Likert scale ranging from 1 (never) to 4 (always).

Perceived supervisor support was measured using the validated and adapted French and Dutch versions of the ad hoc subscale of the Survey of Perceived Organisational Support (Eisenberger et al., 1986). For each of the four items, the term 'organisation' was replaced by the term 'supervisor' (e.g. 'My supervisor really cares about my well-being'). Participants responded to a seven-point Likert-type scale ranging from 1 (strongly disagree) to 7 (strongly agree).

Recognition from supervisors was measured with the five French items ad hoc subscale developed by Fall (2015), for example, 'My superiors congratulate me or thank me for highlighting a good job'. The response scale ranged from 1 (strongly disagree) to 5 (strongly agree).

Work-to-family conflict and WFE were measured using the validated French version of the two ad hoc subscales of the Survey Work-Home Interaction - Nijmegen (i.e. eight items for WFC subscale, e.g. 'I'm irritable at home because my work is demanding'; five items for WFE subscale, e.g. 'I come home cheerfully after a successful day at work, positively affecting the atmosphere at home'; Hansez, Etienne, \& Geurts, 2006). Participants answered using a four-point Likert-type scale (0: never to 3: always).

Work engagement was measured using the validated French and Dutch short versions of the Utrecht Work Engagement Scale (Schaufeli et al., 2002). The scale includes three dimensions: vigour (three items; e.g. 'At my work, I feel bursting of energy'), dedication (three items; e.g. 'I am enthusiastic about my job') and absorption (three items; e.g. 'I feel happy when I am working intensely'). The response scale ranged from 1 (strongly disagree) to 7 (strongly agree).

Burnout was measured using the validated French and Dutch versions of the Oldenburg Burnout Inventory (OLBI) (Demerouti, Bakker, Vardakou, \& Kantas, 2003). The OLBI evaluates burnout using two dimensions: exhaustion with eight items (e.g. 'After my work, I regularly feel worn out and weary') and disengagement with eight items (e.g. 'I frequently talk about my work in a negative way'). Participants were asked to respond by using a four-point Likert scale ranging from 1 (strongly disagree) to 4 (strongly agree).

Covariates. Based on the full partial method recommended by Little (2013), we accounted for the influence of covariates by specifying paths from all socio-demographic variables included in our survey to all endogenous and exogenous variables. After running this initial model, we removed the non-significant effects. We thus statistically controlled two socio-demographic variables, that is, gender was significantly related to WFE and the number of hours worked per week was significantly related to WFC. As recommended by Becker 
et al. (2016, p. 162), the inclusion of control variables has to be based on 'relevant theory, or at least on sound reasoning and empirical evidence'. Women were found to experience higher levels of positive work-to-family interface than do men (e.g. Van Steenbergen, Ellemers, \& Mooijaart, 2007). Higher number of work hours was found to increase the perception of WFC (e.g. Grzywacz \& Marks, 2000). Consequently, we included these two socio-demographic variables as covariates in our analyses.

\section{Statistical analysis}

Analyses were performed using Mplus 6 (Muthén \& Muthén, 2010). We assessed the measurement models through a series of confirmatory factor analyses to evaluate the independence of constructs examined in our study. Concerning hypotheses 1 and 2, we proceeded with the assessment of the hypothesised structural relationships amongst latent variables. We used the bootstrapping technique to estimate indirect effects (Preacher \& Hayes, 2008). Concerning Hypothesis 3, we tested the moderation hypotheses using the two-step estimation procedure proposed by Klein and Moosbrugger (2000) for estimating latent moderated structural (LMS) equations in Mplus. By using the balancing technique (Little, Cunningham, Shahar, \& Widaman, 2002), we reduced the number of items to three for each factor (except for work engagement because the three sub-dimensions were already evaluated using three items).

\section{Results \\ Measurement models}

We compared several nested models in order to test the distinctiveness of the constructs included in our study. Firstly, we examined the fit of our hypothesised 11-factor model (that comprises emotional load, workload, recognition from superiors, perceived supervisors support, exhaustion, disengagement, vigour, dedication and absorption) as well as a series of more constrained measurement models. Chi-square difference tests were used to compare the fit of these nested models with that of the 11-factor model. Results indicated that the 11-factor model was significantly superior to all alternative models.

Consequently, we treated these 11 constructs as independent from each other in subsequent analyses. Table 1 presents fit indices of some of these alternative models.

\section{Relationships amongst variables}

Means, standard deviations, Cronbach's alphas and correlations amongst variables are presented in Table 2.

Internal consistency reliabilities ranged from 0.72 to 0.93 . Table 3 presents fit indices for the hypothesised structural model (Model 0) and several alternative models (models 1-20). In all models, disturbance terms of our outcomes were allowed to correlate. Model 0 fit the data reasonably well, as

TABLE 1: Fit indices for measurement models $(N=226)$.

\begin{tabular}{|c|c|c|c|c|c|c|c|c|}
\hline No. & Model & $d f$ & $\chi^{2}$ & RMSEA & CFI & Model comparisons & $\Delta \chi^{2}$ & $\Delta d f$ \\
\hline 1 & 11-factor model & 440 & 905.76 & 0.07 & 0.914 & - & - & - \\
\hline 2 & 10-factor model (eload and wload) & 450 & 1049.38 & 0.08 & 0.889 & 1 vs. 2 & 143.62 & $10 * * *$ \\
\hline 3 & 10-factor model (pss and recs) & 450 & 1026.87 & 0.08 & 0.893 & 1 vs. 3 & 121.11 & $10 * * *$ \\
\hline 4 & 10-factor model (wfe and wfc) & 450 & 1317.05 & 0.09 & 0.839 & 1 vs. 4 & 411.29 & $10 * * *$ \\
\hline 5 & 10-factor model (ex and dis) & 450 & 1047.52 & 0.08 & 0.889 & 1 vs. 5 & 141.77 & $10 * * *$ \\
\hline 6 & 10-factor model (vi and de and ab) & 459 & 1191.70 & 0.08 & 0.864 & 1 vs. 6 & 285.95 & $19 * * *$ \\
\hline
\end{tabular}

Note: For the evaluation of the model fit, the following cut-off points were used: for the RMSEA, values of 0.08 or lower; and for the CFI, values of 0.90 or higher (Kline, 2005 ).

Eload, emotional load; wload, workload; recs, recognition from supervisors; pss, perceived supervisors support; ex, exhaustion; dis, disengagement; vi, vigour; de, dedication; ab, absorption; $d f$, degrees of freedom; Chi, minimum fit function Chi-square; RMSEA, root-mean-square error of approximation; CFI, comparative fit index; vs., versus; No., number.

***, $p<0.001$

TABLE 2: Descriptive statistics and inter-correlations amongst variables $(N=226)$.

\begin{tabular}{|c|c|c|c|c|c|c|c|c|c|c|c|c|c|c|}
\hline No. & Variables & M & SD & 1 & 2 & 3 & 4 & 5 & 6 & 7 & 8 & 9 & 10 & 11 \\
\hline 1 & Workload & 2.42 & 0.58 & $(0.77)$ & - & - & - & - & - & - & - & - & - & - \\
\hline 2 & Emotional load & 2.02 & 0.72 & $0.34 * *$ & $(0.72)$ & - & - & - & - & - & - & - & - & - \\
\hline 3 & $\begin{array}{l}\text { Support from } \\
\text { supervisors }\end{array}$ & 4.28 & 1.68 & $-0.14 *$ & $-0.31 * *$ & $(0.90)$ & - & - & - & - & - & - & - & - \\
\hline 4 & $\begin{array}{l}\text { Recognition from } \\
\text { supervisors }\end{array}$ & 4.40 & 1.61 & $-0.13 *$ & $-0.20 * *$ & $0.77 * *$ & $(0.93)$ & - & - & - & - & - & - & - \\
\hline 5 & $\begin{array}{l}\text { Work-to-family } \\
\text { conflict }\end{array}$ & 0.68 & 0.76 & $0.48 * *$ & 0.10 & $-0.34 * *$ & $-0.12 *$ & $(0.91)$ & - & - & - & - & - & - \\
\hline 6 & $\begin{array}{l}\text { Work-to-family } \\
\text { enrichment }\end{array}$ & 0.80 & 0.79 & -0.03 & 0.02 & $0.13^{*}$ & $0.26 * *$ & $-0.13 *$ & $(0.84)$ & - & - & - & - & - \\
\hline 7 & Disengagement & 2.38 & 0.75 & $0.15^{*}$ & $0.18 * *$ & $-0.47 * *$ & $-0.49 * *$ & $0.38 * *$ & $-0.30 * *$ & $(0.89)$ & - & - & - & - \\
\hline 8 & Exhaustion & 2.43 & 0.75 & $0.30 * *$ & $0.35 * *$ & $-0.44 * *$ & $-0.40 * *$ & $0.52 * *$ & $-0.24 * *$ & $0.56 * *$ & $(0.86)$ & - & - & - \\
\hline 9 & Vigour & 4.57 & 1.09 & -0.13 & -0.09 & $0.42 * *$ & $0.47 * *$ & $-0.35 * *$ & $0.30 * *$ & $-0.61 * *$ & $-0.52 * *$ & $(0.83)$ & - & - \\
\hline 10 & Dedication & 4.74 & 1.31 & -0.01 & -0.02 & $0.32 * *$ & $0.42 * *$ & -0.09 & $0.28 * *$ & $-0.68 * *$ & $-0.38 * *$ & $0.65 * *$ & $(0.93)$ & - \\
\hline 11 & Absorption & 4.40 & 1.20 & $0.20 * *$ & 0.10 & $0.21 * *$ & $0.33 * *$ & $0.15^{*}$ & 0.11 & $-0.45 * *$ & $-0.18 * *$ & $0.52 * *$ & $0.71 * *$ & $(0.82)$ \\
\hline
\end{tabular}

Note: Correlations amongst variables are provided below the diagonal and Cronbach's alphas are provided on the diagonal.

$M$, mean; $S D$, standard deviation; No., number.

*, $p<0.05$; **, $p<0.01$. 
indicated by the following indices: $\chi^{2}(d f)=1060.85(525)$, rootmean-square error of approximation (RMSEA) $=0.07$, comparative fit index $(\mathrm{CFI})=0.90$. We compared this Model 0 with 20 alternative nested models containing additional paths that were theoretically plausible. The Chi-square difference test was used to compare the fit of these alternative nested models with that of Model 0. Results of the comparisons indicated that Model 19 fit the data reasonably well $\left(\chi^{2}[d f]=1023.90(520)\right.$, RMSEA $\left.=0.07, \mathrm{CFI}=0.91\right)$ and was significantly superior to all models. We thus retained Model 19 as the best fitting model. In Model 19 we added, starting from Model 0: (1) a path from emotional load to exhaustion, (2) paths from recognition from supervisors to disengagement, vigour and absorption and (3) a path from perceived supervisor support to dedication.

Standardised parameter estimates for this model are shown in Figure 2. For ease of presentation, we show the structural

TABLE 3: Fit indices for structural models $(N=226)$.

\begin{tabular}{|c|c|c|c|c|c|c|c|c|}
\hline MNo. & Models & $d f$ & $\delta^{2}$ & RMSEA & CFI & Model comparisons & $\Delta \chi^{2}$ & $\Delta d f$ \\
\hline$\overline{\mathrm{MO}}$ & Hypothesised theoretical model & 525 & 1060.85 & 0.07 & 0.90 & - & - & - \\
\hline M1 & $\mathrm{MO}+$ paths between eload and ex & 524 & 1051.83 & 0.07 & 0.90 & M0 vs. M1 & 9.02 & $1 * *$ \\
\hline M2 & M1 + paths between eload and dis & 523 & 1049.19 & 0.07 & 0.90 & $\mathrm{M} 2$ vs. $\mathrm{M} 1$ & 2.64 & 1 \\
\hline M3 & $\mathrm{M} 1$ + paths between eload and vi & 523 & 1051.80 & 0.07 & 0.90 & M3 vs. M1 & 0.03 & 1 \\
\hline M4 & M1 + paths between eload and de & 523 & 1048.31 & 0.07 & 0.90 & M4 vs. M1 & 3.52 & 1 \\
\hline M5 & M1 + Paths between eload and ab & 523 & 1051.78 & 0.07 & 0.90 & M5 vs. M1 & 0.05 & 1 \\
\hline M6 & M1 + Paths between wload and ex & 523 & 1051.56 & 0.07 & 0.90 & M6 vs. M1 & 0.27 & 1 \\
\hline M7 & M1 + Paths between wload and dis & 523 & 1051.90 & 0.07 & 0.90 & M7 vs. M1 & 0.06 & 1 \\
\hline M8 & M1 + Paths between wload and vi & 523 & 1051.52 & 0.07 & 0.90 & M8 vs. M1 & 0.31 & 1 \\
\hline M9 & M1 + Paths between wload and de & 523 & 1051.73 & 0.07 & 0.90 & M9 vs. M1 & 0.10 & 1 \\
\hline M10 & M1 + Paths between wload and ab & 523 & 1048.48 & 0.07 & 0.90 & M10 vs. M1 & 3.36 & 1 \\
\hline M11 & $\mathrm{M} 1+$ Paths between recs and ex & 523 & 1051.61 & 0.07 & 0.90 & M11 vs. M1 & 0.23 & 1 \\
\hline M12 & M1 + Paths between recs and dis & 523 & 1042.27 & 0.07 & 0.90 & M12 vs. M1 & 9.56 & $1 * *$ \\
\hline M13 & M12 + Paths between recs and vi & 522 & 1037.82 & 0.07 & 0.90 & M13 vs. M12 & 4.45 & $1^{*}$ \\
\hline M15 & M13 + Paths between recs and ab & 521 & 1029.70 & 0.07 & 0.91 & M15 vs. M13 & 8.12 & $1 * *$ \\
\hline M16 & M15 + Paths between pss and ex & 520 & 1026.05 & 0.07 & 0.91 & M16 vs. M15 & 3.65 & 1 \\
\hline M17 & M15 + Paths between pss and dis & 520 & 1029.26 & 0.07 & 0.91 & M17 vs. M15 & 0.44 & 1 \\
\hline M18 & M15 + Paths between pss and vi & 520 & 1029.26 & 0.07 & 0.91 & M18 vs. M15 & 0.44 & 1 \\
\hline M19 & M15 + Paths between pss and de & 520 & 1023.90 & 0.07 & 0.91 & M19 vs. M15 & 5.80 & $1 * *$ \\
\hline $\mathrm{M} 20$ & M19 + Paths between pss and ab & 519 & 1023.38 & 0.07 & 0.91 & M20 vs. M19 & 0.52 & 1 \\
\hline
\end{tabular}

Note: For the evaluation of the model fit, the following cut-off points were used: for the RMSEA, values of 0.08 or lower; and for the CFI, values of 0.90 or higher (Kline, 2005).

MNo., model number; Eload, emotional load; wload, workload; recs, recognition from superiors; pss, perceived supervisors support; ex, exhaustion; dis, disengagement; vi, vigour; de, dedication; ab, absorption; $d f$, degrees of freedom; chi', minimum fit function Chi-square; RMSEA, root-mean-square error of approximation; CFI, comparative fit index.

$*, p<0.005 ; * *, p<0.01$.

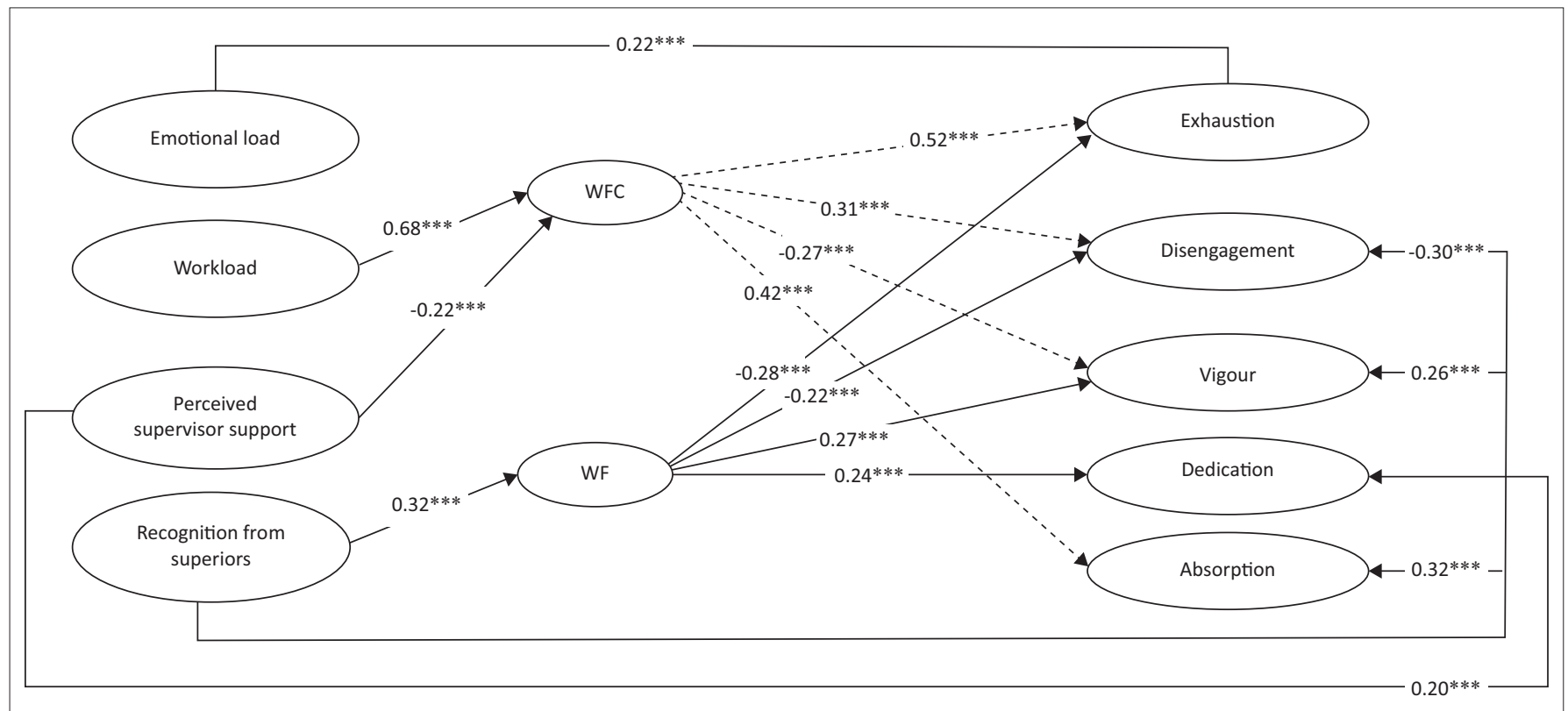

WFC, work-to-family conflict; WFE, work-to-family enrichment. For the sake of clarity, only structural relationships are shown.

Note: To improve readability, the significant paths between WFC and the well-being outcomes have been symbolised with dotted lines.

$* *, p<0.01 ; * * *, p<0.001$.

FIGURE 2: Completely standardised path coefficients for the retained model (Model 19). 
model rather than the full measurement model. Amongst the four independent variables included in the model, only two were significantly related to WFC. Workload and perceived supervisor support were found to be, respectively, positively and negatively associated with WFC. In turn, WFC was found to be positively associated with exhaustion, disengagement and absorption and was negatively associated with vigour. As specified in Table 4, the results of the bootstrap analyses indicated that the indirect effects of workload on burnout and work engagement (except dedication) through WFC were significant, with WFC playing the role of a total mediator. These findings partially supported Hypothesis 1a (i.e. WFC will mediate the relationships between job demands and well-being). The indirect effects of perceived supervisor support on burnout and work engagement (except dedication) through WFC were significant (see Table 4), with WFC playing the role of a total mediator. These findings partially supported Hypothesis 1b (i.e. WFC will mediate the relationships between job resources and well-being).

Only one of the four independent variables studied was significantly related to WFE. This finding did not support Hypothesis 2a (i.e. WFE will mediate the relationships between job demands and well-being).

Recognition from supervisors was found to be positively associated with WFE. In turn, WFE was found to be negatively associated with exhaustion and disengagement and was positively associated with vigour and dedication. Moreover, recognition from supervisors was also directly and negatively related to disengagement and positively related to vigour. The indirect effects of recognition from supervisors on burnout and work engagement (except absorption) through WFE were significant (see Table 4). Thus, WFE totally mediated the effects of recognition from supervisors on exhaustion and dedication.

TABLE 4: Indirect pathways using bootstrapping (Hypotheses 1 and 2) $(N=226$ ).

\begin{tabular}{|c|c|c|c|c|}
\hline \multirow[t]{2}{*}{ Indirect effect: $x \rightarrow m \rightarrow y$} & \multicolumn{2}{|c|}{ Bootstrapping } & \multicolumn{2}{|c|}{ Percentile $95 \% \mathrm{Cl}$} \\
\hline & Effect & SE & Lower & Upper \\
\hline Workload $\rightarrow$ WFC $\rightarrow$ exhaustion & 0.351 & 0.072 & 0.166 & 0.492 \\
\hline Workload $\rightarrow$ WFC $\rightarrow$ disengagement & 0.212 & 0.053 & 0.109 & 0.315 \\
\hline Workload $\rightarrow$ WFC $\rightarrow$ vigour & -0.187 & 0.058 & -0.301 & -0.073 \\
\hline Workload $\rightarrow$ WFC $\rightarrow$ absorption & 0.28 & 0.064 & 0.157 & 0.406 \\
\hline $\begin{array}{l}\text { Perceived supervisor support } \rightarrow \\
\text { WFC } \rightarrow \text { exhaustion }\end{array}$ & -0.110 & 0.047 & -0.202 & -0.019 \\
\hline $\begin{array}{l}\text { Perceived supervisor support } \rightarrow \\
\text { WFC } \rightarrow \text { disengagement }\end{array}$ & -0.067 & 0.027 & -0.120 & -0.013 \\
\hline $\begin{array}{l}\text { Perceived supervisor support } \rightarrow \\
\text { WFC } \rightarrow \text { vigour }\end{array}$ & 0.059 & 0.028 & 0.005 & 0.113 \\
\hline $\begin{array}{l}\text { Perceived supervisor support } \rightarrow \\
\text { WFC } \rightarrow \text { absorption }\end{array}$ & -0.089 & 0.033 & -0.154 & -0.023 \\
\hline $\begin{array}{l}\text { Recognition from supervisors } \rightarrow \\
\text { WFE } \rightarrow \text { exhaustion }\end{array}$ & -0.089 & 0.029 & -0.145 & -0.033 \\
\hline $\begin{array}{l}\text { Recognition from supervisors } \rightarrow \\
\text { WFE } \rightarrow \text { disengagement }\end{array}$ & -0.069 & 0.028 & -0.124 & -0.013 \\
\hline $\begin{array}{l}\text { Recognition from supervisors } \rightarrow \\
\text { WFE } \rightarrow \text { vigour }\end{array}$ & 0.087 & 0.028 & 0.033 & 0.141 \\
\hline $\begin{array}{l}\text { Recognition from supervisors } \rightarrow \\
\text { WFE } \rightarrow \text { dedication }\end{array}$ & 0.075 & 0.027 & 0.023 & 0.127 \\
\hline
\end{tabular}

Note: 10000 bootstrap samples.

WFC, work-to-family conflict; WFE, work-to-family enrichment; SE, standard error; $\mathrm{Cl}$, confidence interval.
Moreover, WFE partially mediated the effects of recognition from supervisors on disengagement and vigour. These findings partially supported Hypothesis $2 b$ (i.e. WFE will mediate the relationships between job resources and well-being).

The results also highlighted three direct effects. Emotional load was found to be positively related to exhaustion. Perceived supervisor support was found to be positively related to dedication. Recognition from supervisors was found to be positively related to absorption.

To investigate moderation, Hypothesis 3, we tested structural models using latent interactions separately. The relative fit of LMS models versus the model without interaction terms was determined using log-likelihood ratio tests. Only two log-likelihood ratio tests were significant, that is, Mod 3: $D=-2[(-8202.999)-(-8200.662)]=4.67(1)(p<0.05) ;$ Mod 4: $D=-2[(-8202.999)-(-8197.915)]=10.17(1)(p<0.01)$. Within Mod 3, the recognition from supervisors $\times$ workload interaction on WFC was significant $(-0.16, S E=0.08, p<0.05)$. High workload when combined with high recognition from supervisors resulted in lower perception of WFC (see Figure $3 \mathrm{a}$ for a graphical representation of this

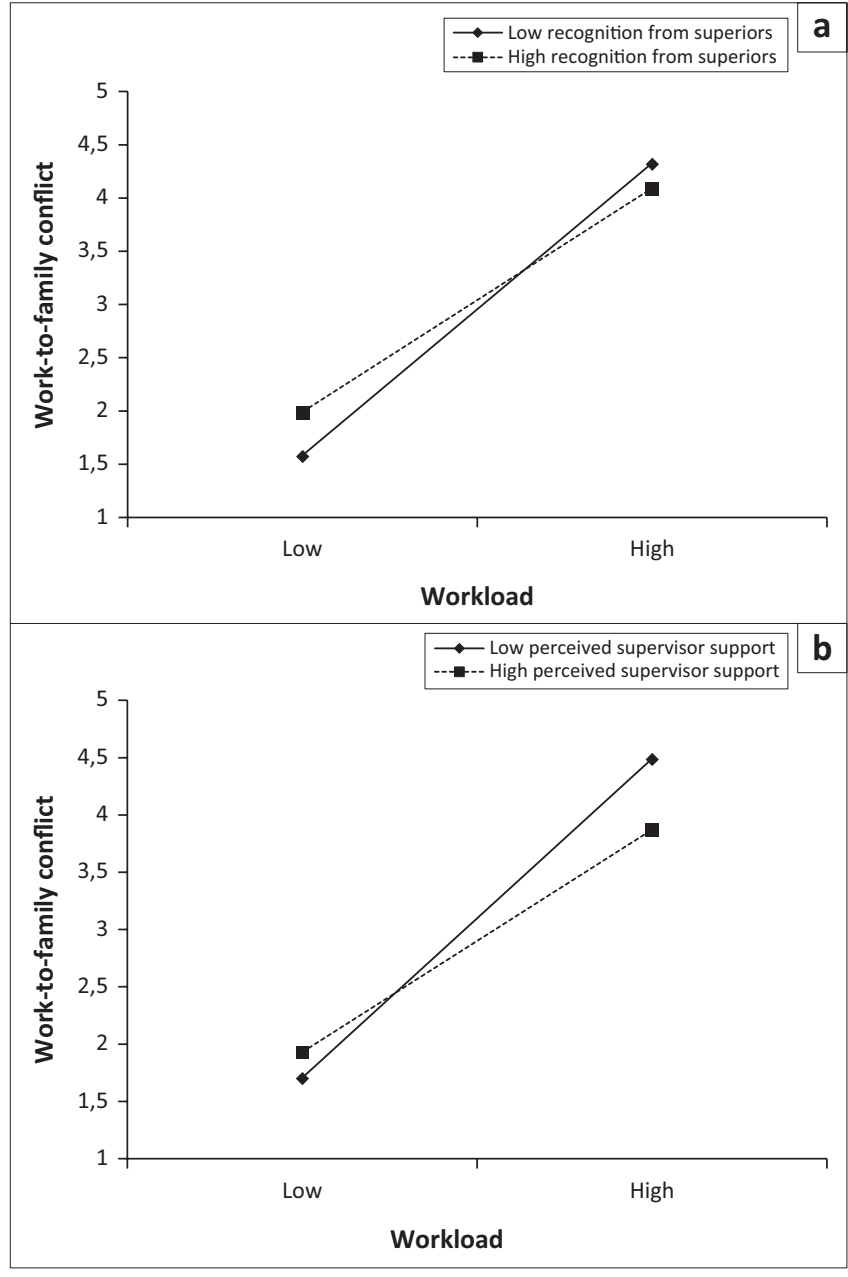

FIGURE 3: Graphical representations of the moderating role of recognition from supervisors: (a) and perceived supervisors support; (b) in the relationship between workload and work-to-family conflict. 
moderation). Within Mod 4, the perceived supervisor support $x$ workload interaction on WFC was significant $(-0.21, S E=0.07, p<0.01)$. High workload when combined with high perceived supervisor support resulted in lower perception of WFC (see Figure $3 b$ for a graphical representation of this moderation). These findings partially supported Hypothesis 3 (i.e. job resources will moderate the relationships between job demands and WFC).

\section{Discussion}

\section{Outline of the results}

Based on recent recommendations (Baeriswyl et al., 2016), the present study had three objectives. The first two objectives consisted of investigating the mediating role of WFC (i.e. hypotheses $1 \mathrm{a}$ and $1 \mathrm{~b}$ ) and WFE (i.e. hypotheses $2 \mathrm{a}$ and $2 b$ ) in the relationships between work environment (i.e. emotional load and workload as job demands; supervisor support and recognition from supervisors as job resources) and well-being outcomes (i.e. work engagement and burnout). The third one consisted of investigating the buffering effect of job resources in the job demands-WFC relationships (i.e. Hypothesis 3). These hypotheses were tested on employees working in the medical division of a Belgian Federal Public Service active in the field of security.

On one hand, our findings indicate that WFC mediates the effects of workload and perceived supervisor support on burnout and work engagement (except the dedication subdimension). These results are consistent with some previous research investigating the relationships between workload and WFC (e.g. Molino et al., 2015), between supervisor support and WFC (e.g. Bowling et al., 2015), between WFC and burnout (e.g. Verweij et al., 2017) and between WFC and work engagement (e.g. Babic et al., 2017). By depleting individual's resources (Bakker \& Demerouti, 2007), workload increases workers' perception of WFC, whereas supervisor support through energising the motivational process (Bakker et al., 2005) reduces the perception of WFC. The resource depletion because of the process of juggling work and family demands (Hobfoll, 2002) leads workers to experience burnout and to reduce their level of vigour in order to protect their remaining resources (Hobfoll, 2002). Surprisingly, WFC is found to be positively related to absorption. This unexpected result could be explained by the reactive compensation theory (Edwards \& Rothbard, 2000) postulating that unpleasant experiences in one domain are remedied by pleasant experiences in another domain. By perceiving unpleasant experiences in their family domain, workers confronted with WFC could make some efforts at work (by being fully concentrated and engrossed in their work) to increase positive experiences within their professional sphere and therefore counter the negative experiences in the family sphere.

On the other hand, our findings indicate that WFE mediates the effects of recognition from supervisors on burnout and work engagement (except the absorption sub-dimension). These results are consistent with some previous research investigating the relationships between WFE and burnout (e.g. Verweij et al., 2017) and between WFE and work engagement (e.g. Wayne et al., 2004). Being recognised by supervisors generates happiness and a positive mood (e.g. Siegrist, 2000), which overflows into the family domain and improves the quality of workers' life in their family sphere, leading them to perceived WFE. The resourcegenerating process resulting in the WFE (Tement \& Korunka, 2015) reduces workers' experience of burnout and increases their level of vigour and dedication to work in order to obtain or gain more resources (Hobfoll, 2002). We found no impact of job demands on WFE experiences. This is consistent with the fact that the relationships between job demands and positive outcomes are less pronounced than the relationships between job demands and negative outcomes (Schaufeli \& Bakker, 2004). This is also in line with the fact that WFE originates mainly in a resource-rich work environment (Carlson et al., 2006).

One interesting finding of the present study concerns the fact that recognition from supervisors is related to WFE, whereas support from supervisors is related to WFC. These results assume that these two job resources operate in different ways regarding work-to-family interface. The fact that WFC is only influenced by supervisor support highlights the importance of social support. When individuals feel socially supported at work, they feel cared for by socially related others and feel that they have access to help (Hobfoll, 2002) and that emotional and tangible support is available when needed (George, Reed, Ballard, Colin, \& Fielding, 1993).

By perceiving more social support, workers' emotional and psychological supplies for coping with daily stressors increase, and perceptual appraisals of stressors decrease (Jex, 1998). By being supportive, supervisors indicate that they are sensitive to the workers' needs (notably their needs related to family obligations). Employees feeling supported by supervisors would expect managers to show greater empathy and emotional support when they are confronted with difficult work-related problems. When individuals have more social support and content specifically for managing work-family issues, these positive dynamics may overflow into the family role, thereby reducing WFC (e.g. Frone, Russell, \& Cooper, 1992).

Support received from supervisors is viewed by workers as a sign that managers take care of their well-being and are sensitive to their needs, thus reducing the resource depletion process induced by WFC.

Recognition from supervisors refers more to the resource generation and motivational processes, therefore increasing the perception of WFE. Indeed, incentives, rewards and recognitions are the prime factors that impact employee motivation (Danish \& Usman, 2010). Implementing effective 
rewards and recognition within an organisation generates a favourable working environment, which motivates employees to perform better in their work (Freedman, 1978). Taking recognition as their feelings of value and appreciation boosts up the morale of workers, which increases their productivity. According to the instrumental path of the enrichment process (Greenhaus \& Powell, 2006), rewards gained are directly transferred from one role to another, and help one to perform better in the receiving domain, increasing workers' perception of WFE. In the same vein, the increased performance at work generated by recognition produces a positive environment at work which seeps in and positively impacts how one feels, acts and behaves in the receiving domain (i.e. affective path of the enrichment process) Greenhaus \& Powell, 2006)

These results emphasise the fact that recognition from supervisors activates the resource generation and motivational processes more, whereas support from supervisors is more important in the resource depletion and health impairment processes. Recognition can motivate and help to build feelings of confidence (Keller, 1999), as well as encourage employees to extend their efforts (Freedman, 1978). Perceiving supervisors as supportive, who take care of worker's well-being, is an important resource for workers. Social support notably reduces the likelihood that work situations will be perceived as stressful impacting the perception of work-family conflict (Carlson \& Perrewe, 1999).

However, the fact that we found no significant relationship between supervisor support and WFE might be explained by the very low level of WFE experienced by the respondents of our study (i.e. mean of 0.80 , range $=0-3$ ). Nicklin and McNall (2013) found that the relationship occurred when WFE was experienced at a higher level. Possibly, within a sample perceiving more WFE, the support-WFE relationship would become significant. According to Greenhaus and Powell (2006), the social capital resources generated from work can improve the quality of life in the family. This issue should be investigated in future studies.

The study findings also indicate some direct effects of work environment on well-being. Firstly, emotional load is positively related to exhaustion. In line with previous studies (e.g. Verweij et al., 2017), emotional load increases exhaustion by draining individuals' resources. The fact that emotional load was found to be unrelated to the second sub-dimension of burnout (i.e. disengagement) is consistent with the fact that job demands relate more strongly with exhaustion than with the other sub-dimensions of burnout (Alarcon, 2011). Secondly, support from supervisors is directly related in a positive way to only one dimension of work engagement, namely, dedication. By fulfilling socio-emotional needs (e.g. Rhoades \& Eisenberger, 2002), support leads workers to be more involved in their work. The effects of support on the other four investigated outcomes were found to be indirect through WFC. Thirdly, recognition from supervisors is directly positively related to vigour and absorption and directly negatively related to disengagement. These results are consistent with some previous research investigating the relationships between recognition from supervisors and work engagement (e.g. Laschinger \& Finegan, 2005) and between recognition from supervisors and burnout (e.g. Amutio et al., 2009). By stimulating the resource generation and motivational processes (Freedman, 1978), recognition from supervisors increases the level of workers' vigour and absorption and reduces workers' level of disengagement. The effects of recognition on the other investigated outcomes (i.e. dedication and exhaustion) were found to be indirect through WFE.

Considering the buffering effects, our findings indicate that both support and recognition from supervisors moderate the positive effect of workload on WFC. These results are consistent with previous research investigating the moderating role of social support (e.g. Xanthopoulou et al., 2007). These results reveal that under demanding work conditions (i.e. perception of workload), employees receiving support and recognition from their supervisors dispose more supplies and, thus, are better able to deal with these demands, protecting them from a negative outpour from the work domain into the private domain (i.e. WFC). This finding is in line with the fact that resources become salient and gain their motivational potential when employees are confronted with demanding jobs (Hobfoll, 2002).

\section{Conclusion}

\section{Limitations and recommendations}

Our study has several limitations, leading us to interpret the findings reported here with caution. The first major limitation is the fact that the data are cross-sectional, precluding any inference of causality amongst the studied constructs. Secondly, the specificity of our data makes it difficult to generalise the results to other professional sectors. Thus, it would be helpful to replicate these results amongst other organisations. Thirdly, as we used self-reported data, common method variance may have biased our results (Podsakoff, MacKenzie, \& Podsakoff, 2012). However, considering that the single-factor model showed a poor fit to the data, this common method bias was partially treated (i.e. Harman's single-factor test; Podsakoff et al., 2012). Despite these limitations, our study has some strong points too. Indeed, this study extends previous research by integrating WFE in the JD-R process to explain well-being. Our study is also in line with theories or models largely acknowledged in the literature (i.e. COR theory; JD-R model; enrichment process). Moreover, by including recognition from supervisors, our study also contributes to the literature considering that, to the best of our knowledge, no previous research has investigated the relationship between recognition and work-to-family interface.

\section{Practical implications}

From a practical perspective, our findings suggest that workload, support and recognition from supervisors may play 
a crucial role in the emergence of WFC, WFE, burnout and work engagement. Promoting a supportive work environment and reducing the workload may contribute to reduce the perception of WFC, and therefore enhance workers' wellbeing. To promote a positive social climate at work, managers have to provide assurance in forms such as empathy for the employee's difficulties, confidence in the employee's abilities and offers of aid as needed. To reduce workload, organisations should, for example, provide workers adequate opportunities to gain control of the amount of time available to spend on various job requirements. Providing training programmes focusing on time and stress management skills could help employees set realistic goals and prioritise them so as to better cope with high workload. However, workload is often difficult to reduce at short notice. But, as suggested by our study, support and recognition from supervisors buffer the impact of workload. Therefore, to inhibit the health impairment process induced by workload, it is important to invest in social support and in social recognition processes. Moreover, if recognition from supervisors buffers the workload-WFC relationship, such job resources also have motivational potential which fosters WFE. To promote recognition, managers could spontaneously praise people, thank the person by name, specifically state what workers did that is being recognised or highlight workers' competencies and value.

\section{Acknowledgements Competing interests}

The authors declare that they have no financial or personal relationships that may have inappropriately influenced them in writing this article.

\section{Authors' contributions}

A.B. was the main project leader, N.G. helped with the data collection and I.H. was the supervisor of the project.

\section{Funding information}

This research received no specific grant from any funding agency in the public, commercial or not-for-profit sectors.

\section{Data availability statement}

Data sharing is not applicable to this article as no new data were created or analysed in this study.

\section{Disclaimer}

The views and opinions expressed in this article are those of the authors and do not necessarily reflect the official policy or position of any affiliated agency of the authors.

\section{References}

Alarcon, G. (2011). A meta-analysis of burnout with job demands, resources, and attitudes. Journal of Vocational Behavior, 79(2), 549-562. https://doi.org/10. 1016/j.jvb.2011.03.007

Amstad, F., Meier, L., Fasel, U., Elfering, A., \& Semmer, N. (2011). A meta-analysis of work-family conflict and various outcomes with a special emphasis on crossdomain versus matching-domain relations. Journal of Occupational Health Psychology, 16(2), 151-169. https://doi.org/10.1037/a0022170.
Amutio, A., Ayestarán, S., \& Smith, J.C. (2009). Assessment of burnout and psychological wellbeing among health professionals in the Basque Country. Psychology in Spain, 13(1), 62-71.

Babic, A., Stinglhamber, F., Bertrand, F., \& Hansez, I. (2017). Work-home interface and well-being: A cross-lagged analysis. Journal of Personnel Psychology, 16(1), 46-55. https://doi.org/10.1027/1866-5888/a000172

Baeriswyl, S., Krause, A., \& Schwaninger, A. (2016). Emotional exhaustion and job satisfaction in airport security officers - Work-family conflict mediator in the job demands-resources model. Frontiers in Psychology, 7, 1-13. https://doi.org/10. 3389/fpsyg.2016.00663

Bakker, A., \& Demerouti, E. (2007). The job demands-resources model: State of the art. Journal of Managerial Psychology, 22, 309-328. https://doi.org/10. art. Journal of Managerial

Bakker, A., \& Demerouti, E. (2008). Towards a model of work engagement. Career Development International, 13, 209-223. https://doi.org/10.1108/136204308 10870476

Bakker, A., \& Demerouti, E. (2017). Job demands-resources theory: Taking stock and looking forward. Journal of Occupational Health Psychology, 22(3), 273-285. https://doi.org/10.1037/ocp0000056

Bakker, A., Demerouti, E., \& Euwema, M. (2005). Job resources buffer the impact of job demands on burnout. Journal of Occupational Health Psychology, 10(2), 170-180. https://doi.org/10.1037/1076-8998.10.2.170

Bakker, A., Hakanen, J., Demerouti, E., \& Xanthopoulou, D. (2007). Job resources boost work engagement, particularly when job demands are high. Journal of Educational Psychology, 99(2), 274-284. https://doi.org/10.1037/0022-0663.99.2.274

Becker, T.E., Atinc, G., Breaugh, J.A., Carlson, K.D., Edwards, J.R., \& Spector, P.E. (2016). Statistical control in correlational studies: 10 essential recommendations for organizational researchers. Journal of Organizational Behavior, 37(2), 157-167. https://doi.org/10.1002/job.2053

Bowling, N., Alarcon, G., Bragg, C., \& Hartman, M. (2015). A meta-analytic examination of the potential correlates and consequences of workload. Work Stress, 29(2), 95-113. https://doi.org/10.1080/02678373.2015.1033037

Boz, M, Martínez-Corts, I., \& Munduate, L. (2016). Types of combined family-to-work conflict and enrichment and subjective health in Spain: A gender perspective. Sex Roles, 74, 136-153. https://doi.org/10.1007/s11199-015-0461-5

Brislin, R.W. (1980). Translation and content analysis of oral and written material. In H. C. Triandis \& J.W. Berry (Eds.), Handbook of cross-cultural psychology (pp. 398-444). Boston, MA: Allyn \& Bacon.

Carlson, D., Kacmar, M., Wayne, J., \& Grzywacz, J. (2006). Measuring the positive side of work-family interface: Development and validation of work-family enrichment scale. Journal of Vocational Behavior, 68(1), 131-164. https://doi.org/10.1016/j. jvb.2005.02.002

Carlson, D., \& Perrewe, P. (1999). The role of social support in the stressor strain relationship: An examination of work-family conflict. Journal of Management, 25(4), 513-540. https://doi.org/10.1177/014920639902500403

Cavanaugh, M.A., Boswell, W.R., Roehling, M.V., \& Boudreau, J.W. (2000). An empirical examination of self-reported work stress among U.S. managers. Journal of Applied Psychology, 85(1), 65-74. https://doi.org/10.1037/0021-9010.85.1.65

Chen, S., Westman, M., \& Eden, D. (2009). Impact of enhanced resources on anticipatory stress and adjustment to new information technology: A fieldexperimental test of conservation of resources theory. Journal of Occupational Health Psychology, 14(3), 219-230. https://doi.org/10.1037/a0015282

Danish, R., \& Usman, A. (2010). Impact of reward and recognition on job satisfaction and motivation: An empirical study from Pakistan. International Journal of Business and Management, 5(2), 159-167. https://doi.org/10.5539/ijbm.v5n2p159

Demerouti, E., Bakker, A., \& Schaufeli, W. (2005). Spillover and crossover of exhaustion and life satisfaction among dual-earner parents. Journal of Vocational Behavior 67(2), 266-289. https://doi.org/10.1016/j.jvb.2004.07.001

Demerouti, E., Bakker, A., Vardakou, I., \& Kantas, A. (2003). The convergent validity of the two burnout instruments: A multitrait-multimethod analysis. European Journal of Psychological Assessment, 19, 12-23. https://doi.org/10.1027//10155759.19.1.12

Dishon-Berkovits, M. (2014). Burnout: Contributing and protecting factors within the work-family interface. Journal of Career Development, 41(6), 467-486. https:// doi.org/10.1177/0894845313512181

Edwards, J., \& Rothbard, N. (2000). Mechanisms linking work and family: Clarifying the relationship between work and family constructs. Academy of Management Review, 25(1), 178-199. https://doi.org/10.2307/259269

Eisenberger, R., Huntington, R., Hutchison, S., \& Sowa, D. (1986). Perceived organizational support. Journal of Applied Psychology, 71(3), 500-507. https:// organizational support. Journal of Appli

Fall, A. (2015). Reconnaissance au travail: Validation d'une échelle de mesure dans le contexte des entreprises. Revue Européenne de Psychologie Appliquée, 65(4), 189-203. https://doi.org/10.1016/j.erap.2015.07.001

Freedman, S. (1978). Some determinants of compensation decisions. The Academy of Management, 21, 397-409. https://doi.org/10.2307/255722

Frone, M., Russell, M., \& Cooper, M. (1992). Antecedents and outcomes of workfamily conflict: Testing a model of the work-family interface. Journal of Applied Psychology, 77(1), 65-78. https://doi.org/10.1037//0021-9010.77.1.65

George, J., Reed, T., Ballard, K., Colin, J., \& Fielding, J. (1993). Contact with AIDS patients as a source of work-related distress: Effects of organizational and social support Academy of Management Journal, 36, 157-171. https://doi.org/10.2307/256516 
Greenhaus, J., \& Beutell, N. (1985). Sources of conflict between work and family roles. Academy of Management Review, 10(1), 76-88. https://doi.org/10.5465/ Academy of Manage
AMR.1985.4277352

Greenhaus, J., \& Powell, G. (2006). When work and family are allies: A theory of workfamily enrichment. Academy of Management Review, 31(1), 72-92. https://doi. org/10.5465/AMR.2006.19379625

Grzywacz, J., \& Butler, A. (2005). The impact of job characteristics on work-to-family facilitation: Testing a theory and distinguishing a construct. Journal of Occupational Health Psychology, 10(2), 97-109. https://doi.org/10.1037/1076-8998.10.2.97

Grzywacz, J., \& Marks, N. (2000). Reconceptualizing the work-family interface: An ecological perspective on the correlates of positive and negative spillove between work and family. Journal of Occupational Health Psychology, 5(1) 111-126. https://doi.org/10.1037/1076-8998.5.1.111

Hansez, I., Etienne, A.M., \& Geurts, S. (2006). Le questionnaire d'interaction travailfamille de Nijmegen: Résultats préliminaires et intérêt pour la clinique. Revue Francophone de Clinique Comportementale et Cognitive, 11(2), 1-13.

Hobfoll, S. (2002). Social and psychological resources and adaptation. Review of General Psychology, 6(4), 307-324. https://doi.org/10.1037/1089-2680.6.4.307

Jex, S. (1998). Stress and job performance: Theory, research, and implications for managerial practice. Thousand Oaks, CA: Sage.

Karasek, R. (1985). Job content questionnaire and user's guide. Lowell: University of Massachusetts.

Keller, J. (1999). Motivational systems. In H. Stolovitch \& E. Keeps (Eds.), Handbook of human performance technology (2nd edn., pp. 373-394). San Francisco, CA Jossey-Bass.

Kinnunen, U., Rantanen, J., Mauno, S., \& Peeters, M. (2014). Work-family interaction. In M. Peeters, J. De Jonge, \& T. Taris (Eds.), An introduction to contemporary work psychology (pp. 267-289). Chichester: Wiley Blackwell.

Klein, A., \& Moosbrugger, H. (2000). Maximum likelihood estimation of latent interaction effects with the LMS method. Psychometrika, 65(4), 457-474. https:// doi.org/10.1007/BF02296338

Kuschel, K. (2017). The work-family field: Gaps and missing links as opportunities for future research. Innovar, 27(66), 57-74. https://doi.org/10.15446/innovar. future research.
v27n66.66711.

Laschinger, H., \& Finegan, J. (2005). Empowering nurses for work engagement and health in hospital settings. Journal of Nursing Administration, 35(10), 439-449. https://doi.org/10.1097/00005110-200510000-00005

LePine, J.A., Podsakoff, N.P., \& LePine, M.A. (2005). A meta-analytic test of the challenge stressor-hindrance stressor framework: An explanation for inconsistent relationships among stressors and performance. Academy of Management Journal, 48(5), 764-775. https://doi.org/10.5465/AMJ.2005.18803921

Little, T. (2013). Longitudinal structural equation modeling. New York: Guilford Press.

Little, T., Cunningham, W., Shahar, G., \& Widaman, K. (2002). To parcel or not to parcel: Exploring the question, weighing the merits. Structural Equation Modeling 9(2), 151-173. https://doi.org/10.1207/S15328007SEM0902_1

Maslach, C., Schaufeli, W.B., \& Leiter, M.P. (2001). Job burnout. Annual Review of Psychology, 52, 397-422. https://doi.org/10.1146/annurev.psych.52.1.397

Merino, D., \& Privado, J. (2015). Does employee recognition affect positive psychological functioning and well-being? Spanish Journal of Psychology, 18, 1-7. hsychological functioning and well-bein

Michel, J., Kotrba, L., Mitchelson, J., Clark, M., \& Baltes, B. (2011). Antecedents of work-family conflict: A meta-analytic review. Journal of Organizational Behavior, 32(5), 689-725. https://doi.org/10.1002/job.695

Molino, M., Cortese, C., Bakker, A., \& Ghislieri, C. (2015). Do recovery experiences moderate the relationship between workload and work-family conflict? Caree Development International, 20(7), 686-702. https://doi.org/10.1108/CDI-012015-0011

Muthén, L., \& Muthén, B. (2010). Mplus User's Guide. 6th edn., Los Angeles, CA Muthén \& Muthén.

Netemeyer, R., Boles, J., \& McMurrian, R. (1996). Development and validation of work-family conflict and family-work conflict scales. Journal of Applied Psychology, 81(4), 400-410. https://doi.org/10.1037/0021-9010.81.4.400

Nicklin, J., \& McNall, L. (2013). Work-family enrichment, support, and satisfaction: A test of mediation. The European Journal of Work and Organizational Psychology, 22(1), 66-77. https://doi.org/10.1080/1359432X.2011.616652

Niedhammer, I., Chastang, J.F., Gendrey, L., David, S., \& Degioanni, S. (2006) Psychometric properties of the French version of Karasek's job content questionnaire and its scales measuring psychological pressures, decisional latitude and social support: The results of the SUMER. Santé Publique, 18(3), 413-427. https://doi.org/10.3917//spub.063.0413
Peeters, M., Montgomery, A., Bakker, A., \& Schaufeli, W. (2005). Balancing work and home: How job and home demands are related to burnout. International Journal of Stress Management, 12(1), 43-61. https://doi.org/10.1037/1072-5245.12.1.43

Podsakoff, N.P., LePine, J.A., \& LePine, M.A. (2007). Differential challenge stressorhindrance stressor relationships with job attitudes, turnover intentions, turnover, and withdrawal behavior: A meta-analysis. Journal of Applied Psychology, 92(2), 438-454. https://doi.org/10.1037/0021-9010.92.2.438

Podsakoff, P., MacKenzie, S., \& Podsakoff, N. (2012). Sources of method bias in social science research and recommendations on how to control it. Annual Review of Psychology, 63, 539-569. https://doi.org/10.1146/annurev-psych-120710-100452

Preacher, K., \& Hayes, A. (2008). Asymptotic and resampling strategies for assessing and comparing indirect effects in multiple mediator models. Behavior Research Methods, 40, 879-891. https://doi.org/10.3758/BRM.40.3.879

Rantanen, J., Kinnunen, U., Mauno, S., \& Tement, S. (2013). Patterns of conflict and enrichment in work-family balance: A three-dimensional typology. Work \& Stress, 27, 141-163. https://doi.org/10.1080/02678373. 2013.791074

Rhoades, L., \& Eisenberger, R. (2002). Perceived organizational support: A review of the literature. Journal of Applied Psychology, 87(4), 698-714. https://doi. org/10.1037//0021-9010.87.4.698

Rich, B., Lepine, J., \& Crawford, E. (2010). Job engagement: Antecedents and effects on job performance. Academy of Management Journal, 53(3), 617-635. https:// doi.org/10.5465/AMJ.2010.51468988

Schaufeli, W., \& Bakker A. (2004). Job demands, job resources, and their relationship with burnout and engagement: A multi-sample study. Journal of Organizational Behavior, 25(3), 293-315. https://doi.org/10.1002/job.248

Schaufeli, W., \& Salanova, M. (2014). Burnout, boredom and engagement at the workplace. In M. Peeters, J. de Jonge \& T. Taris (Eds.), People at work: An introduction to contemporary work psychology (pp. 293-320). Chichester: WileyBlackwell.

Schaufeli, W., Salanova, M., González-Romá, V., \& Bakker, A. (2002). The measurement of engagement and burnout: A two sample confirmative confirmatory factor analytic approach. Journal of Happiness Studies, 3, 71-92. https://doi. org/10.1023/A:1015630930326

Schaufeli, W., \& Taris, T.W. (2005). Commentary. The conceptualization and measurement of burnout: Common ground and worlds apart. Work \& Stress, 19(3), 356-262. https://doi.org/10.1080/02678370500385913

Seligman, M.E.P., \& Csikszentmihalyi, M. (2000). Positive psychology: An introduction American Psychologist, 55(1), 5-14. https://doi.org/10.1037/0003-066X.55.1.5

Sieber, S. (1974). Toward a theory of role accumulation. American Sociological Review, 39(4), 567-578. https://doi.org/10.2307/2094422

Siegrist, J. (2000). A theory of organizational stress. In J. Durham (Ed.) Stress in the workplace: Past, present, and future (pp. 52-66). London: Whurr Publishers.

Tement, S., \& Korunka, C. (2015). The moderating impact of types of caregiving on job demands, resources, and their relation to work-to-family conflict and enrichment. Journal of Family Issues, 36(1), 31-55. https://doi.org/10.1177/ 0192513X13483971

Van Steenbergen, E., Ellemers, N., \& Mooijaart, A. (2007). How work and family can facilitate each other: Distinct types of work-family facilitation and outcomes for women and men. Journal of Occupational Health Psychology, 12(3), 279-300. https://doi.org/10.1037/1076-8998.12.3.279

Van Veldhoven, M., \& Meijman, T. (1994). Het meten van psychosociale arbeidsbelasting met een vragenlijst: De vragenlijst beleving en beoordeling van de arbeid (VBBA). Amsterdam: Nederlands Instituut voor Arbeidsomstandigheden (NIA).

Verweij, H., Van der Heijden, F., Van Hooff, M., Prins, J., Lagro-Janssen, A., Van Ravesteijn, H., Speckens, A. (2017). The contribution of work characteristics, home characteristics and gender to burnout in medical residents. Advances in Health Sciences Education, 22(4), 803-818. https://doi.org/10.1007/s10459-016-9710-9

Wayne, J., Musisca, N., \& Fleeson, W. (2004). Considering the role of personality in the work-family experience: Relationships of the big five to work-family conflict and facilitation. Journal of Vocational Behavior, 64(1), 108-130. https://doi. org/10.1016/S0001-8791(03)00035-6

Xanthopoulou, D., Bakker, A.B., Dollard, M.F., Demerouti, E., Schaufeli, W.B., Taris, T.W., \& Schreurs P.J.G. (2007). When do job demands particularly predict burnout? The moderating role of job resources. Journal of Managerial Psychology, 22(8), 766-786. https://doi.org/10.1108/02683940710837714

Yoo, J., J-E., Shin, S.-Y., \& Yang, I.-S. (2006). Key attributes of internal service recovery strategies as perceived by frontline food service employees. Hospitality Management, 25(3), 496-509. https://doi.org/10.1016/j.ijhm.2005.01.002

Zhang, Y., Xu, S., Jin, J., \& Ford, M. T. (2018). The within and cross domain effects of work-family enrichment: A meta-analysis. Journal of Vocational Behavior, 104, 210-227. https://doi.org/10.1016/j.jvb.2017.11.003 